\title{
Envelope method for the germination test of Mombasa grass
}

\section{Método do envelope para o teste de germinação de sementes de capim-mombaça}

\author{
Tatiane Sanches Jeromini1*; Murilo Petrassi Botassini²; Renato Téo de Barros; \\ Cibele Chalita Martins ${ }^{3}$
}

\section{Highlights}

The envelope method saves time and materials.

The envelope method is equivalent or superior that the traditional method.

The envelope method can be used in species with small seeds.

It allows better use of the germination chamber space.

\begin{abstract}
The Rules for Seed Analysis reports the use of a paper envelope to allow use of the germination test with small seeds but does not provide any method or use recommendation. As Mombasa grass has high quality and commercial importance, the objective of this study was to evaluate the viability of the envelope method in the germination test of Mombasa grass seeds, with the aim of achieving greater result accuracy and improvement of seed quality analysis processes in laboratories. The germination of eight lots of Mombasa grass seeds was evaluated with two sowing methods (on paper and in paper envelope). The moisture content and the first germination count were also determined. The experiment was conducted with a completely randomized design. The data were analyzed in a $2 \times 8$ factor scheme (sowing methods $x$ lots), with four repetitions. The data were subjected to analysis of variance using the $F$ test and when significant, treatment means were compared using the Tukey's test at 5\% probability. Results showed that the envelope method is efficient for the germination test of Mombasa grass seeds and can be easily used by seed analysis laboratories, as it present results equivalent or superior to those obtained using the traditional method on paper, while occupying only $2 / 5$ of the germination chamber space used in the conventional method.
\end{abstract}

Key words: Economics. Efficiency. Seed laboratory. Panicum maximum.

1 PhD Students of the Graduate Program in Agronomy (Plant Production), São Paulo State University "Júlio de Mesquita Filho", School of Agrarian and Veterinary Sciences, FCAV, Jaboticabal, SP, Brazil. E-mail: tatiane_jeromini@hotmail. com; renato.barros@unesp.br

2 Student Graduate, Taquaritinguense Institute of Higher Education, ITES, Taquaritinga, SP, Brazil. E-mail: murilo_ petrassi110@hotmail.com

${ }^{3}$ Full Prof., São Paulo State University "Júlio de Mesquita Filho", School of Agrarian and Veterinary Sciences, FCAV, Jaboticabal, SP, Brazil. E-mail: cibele.chalita@unesp.br

* Author for correspondence

Received: Aug. 24, 2020 - Approved: Dec. 03, 2020 


\section{Resumo}

Nas Regras para Análise de Sementes há relato do uso de envelope de papel para o teste de germinação em sementes pequenas, porém sem qualquer descrição do método ou recomendação de utilização. Sabendose que o capim-mombaça, possui alta qualidade e importância comercial e visando maior precisão dos resultados e aperfeiçoamento dos processos de análise de qualidade de sementes dentro de laboratórios, objetivou-se com a presente pesquisa avaliar a viabilidade do método do envelope na condução do teste de germinação de sementes de capim-mombaça. A germinação de oito lotes de sementes de capim-mombaça foi avaliada por meio de dois métodos de semeadura (sobre papel e em envelope de papel). Também se determinou o teor de umidade e a primeira contagem de germinação. O experimento foi realizado em delineamento inteiramente casualizado. Os dados foram analisados em esquema fatorial 2x8 (métodos de semeadura x lotes), com quatro repetições. Os dados foram submetidos à análise de variância pelo teste $\mathrm{F}$ e quando significativo, as médias dos tratamentos foram comparadas por meio do teste de Tukey a $5 \%$ de probabilidade. Concluiu-se que o método do envelope é eficiente para o teste de germinação de sementes de capim-mombaça e pode ser facilmente adotado pelos laboratórios de análise de sementes, apresentando resultados iguais ou superiores aqueles obtidos pelo método tradicional sobre papel, além de ocupar apenas $2 / 5$ do espaço da câmara de germinação que era utilizado no método convencional.

Palavras-chave: Economia. Eficiência. Laboratório de sementes. Panicum maximum.

Brazil is the largest producer, consumer, and exporter of fodder grass seeds in the world, with Panicum maximum Jacq. being one of the most widely produced species (Associação Brasileira de Sementes e Mudas [ABRASEM], 2016).

Of the commercial cultivars of this species, cv. Mombasa, known as Mombasa grass, stands out for its high dry matter production capacity, high fodder quality, easy establishment, animal acceptability, capacity to emit robust tillers, and tolerance to drought (Mendonça, Mello, Pereira, Silva, \& Yano, 2014). Germination test results are used to evaluate the seed lots for commercialization, quality control of the companies, and determination of the sowing rate in the field. This is the main parameter used for the evaluation of physiological quality of fodder grass seeds (Tomaz, Martins, Silva, \& Vieira, 2016; Melo, Martins, Silva, Pereira, \& Jeromini, 2018).
Laboratories follow a standard germination procedure recommended by Rules for Analysis of Seeds (RAS) (Ministério da Agricultura, Pecuária e Abastecimento [MAPA] (2008) to install, conduct, and evaluate the test, to maintain optimal germination conditions for each species. These procedures are periodically updated to allow for greater result accuracy and process improvement (Tomaz et al., 2016; Jeromini, Muniz, Silva, \& Martins, 2019). According to the norms (MAPA, 2008), the germination test for Mombasa grass should use the sowing on paper method, packed inside transparent plastic boxes (11.0 $\times 11.0 \times 3.5 \mathrm{~cm}$ ) that are usually called "Gerbox" laboratory routine, which should be kept at 20$30^{\circ} \mathrm{C}$ or $15-35^{\circ} \mathrm{C}$ for 28 days, when the final count of the germinated seeds is performed. This is the routine procedure (Melo et al., 2018; Machado, Cruz, Silva, Carneiro, \& Silva, 2019a; Pereira, Martins, Jeromini, Gomes, \& Torres, 2020). 
The last version of the RAS (MAPA, 2009 ) included the use of a paper envelope for this test, but without mentioning preparation procedures and conduct or which species could be analyzed with this procedure, making it difficult for laboratories to understand and reproduce this methodology. Jeromini et al. (2019) developed a protocol for making envelopes for onion seed germination testing and obtained promising results. These researchers reported that the envelope method was faster than the traditional method on paper in transparent plastic boxes, in terms of the time spent for installation, seeding, and disassembly. This result could help companies to save time and labor, which were highlighted as key qualities in quality control testing (Tomaz et al., 2016; Jeromini et al., 2019). Additionally, Jeromini et al. (2019) also reported better use of the internal space of the germination chambers, with lower demand for equipment. The researchers reported that the envelope method allowed the packing of 200 subsamples inside a germination chamber while the traditional method with transparent plastic boxes and blotting paper allowed the allocation of only 60 subsamples. Due to the advantages presented, the envelope method needs to be evaluated for other species particularly those with small seed sizes, such as Mombasa grass (MAPA, 2009).

The use of as many lots as possible in this method, is one point that should be carefully analyzed in the establishment of tests to evaluate the physiological quality of seeds because the test should be developed to be used with lots with different levels of vigor (G. Z. da Silva, Martins, Cruz, Jeromini, \& Bruno, 2017; G. Z. da Silva, Martins, Bruno, Pereira, \& Jeromini, 2019; Pereira et al., 2020). In view of the above, the objective of this study was to evaluate the viability of the envelope method in the germination test of Mombasa grass seeds. A total of nine Panicum maximum cv. Mombasa seed lots were evaluated, six from the state of São Paulo (SP) and three from Goiás (GO) lots 1,5 and 8 from Auriflama - SP $\left(20^{\circ} 41^{\prime} 08^{\prime \prime S}\right.$ $50^{\circ} 33^{\prime} 17^{\prime \prime}$ W with $482 \mathrm{~m}$ altitude), lots 2,3 and 6 from Guzolândia - SP (20³8'59"S 50³9'43"W with $465 \mathrm{~m}$ altitude) and lots 4 and 7 from Quirinópolis - GO (18²6'54"S 50²7'06"W with $541 \mathrm{~m}$ altitude).

The seeds were sent to the Laboratory of Seed Analysis of the Plant Production Department of the School of Agricultural and Veterinary Sciences, UNESP, Jaboticabal campus, where they were stored in a dry chamber under $18^{\circ} \mathrm{C}$ and $50 \% \mathrm{RH}$ to maintain physiological quality during the experiment. After cleaning and obtaining the pure seed portion, each lot was evaluated for the water content of the seeds. This was determined by the greenhouse method, with two subsamples of $0.5 \mathrm{~g}$ at $105 \pm 3^{\circ} \mathrm{C}$ for 24 hours (MAPA, 2009).

The seed lots were evaluated with the two sowing methods: i - on paper, and ii - in paper envelopes. The papers were autoclaved and moistened with 2.5 times the paper mass in distilled water before sowing.

i - sowing on paper: this was the control treatment, as it is the traditional germination method for fodder seeds. In this process, two sheets of blotting paper were packed inside transparent plastic boxes $(11.0 \times 11.0 \times 3.5$ $\mathrm{cm}$ ) with a lid, and 50 seeds were sown on the substrate in four subsamples. The boxes were placed in transparent plastic bags to maintain substrate humidity (Gaspar-Oliveira, Martins, Nakagawa, \& Tomaz, 2007). 
ii - sowing in a paper envelope: two rows of 25 seeds were sown on a sheet of Germitest paper arranged horizontally in the upper half of the sheet. The seeds were sown with a 50-hole sized seed ruler that was used as a template for seed allocation (Figure 1A). Thus, 50 seeds were sown in four subsamples per lot, as in the control treatment. For the preparation of the envelope the sheet was folded as described by Jeromini et al. (2019). The envelopes were packed inside transparent plastic boxes with lids $(32.0 \times 20.0 \times 9.0 \mathrm{~cm})$, in an inclined position forming a $45^{\circ}$ horizontal angle (Figure 1B).

The space required to conduct the tests inside the germination chambers was also evaluated by counting the number of subsamples per chamber.

A
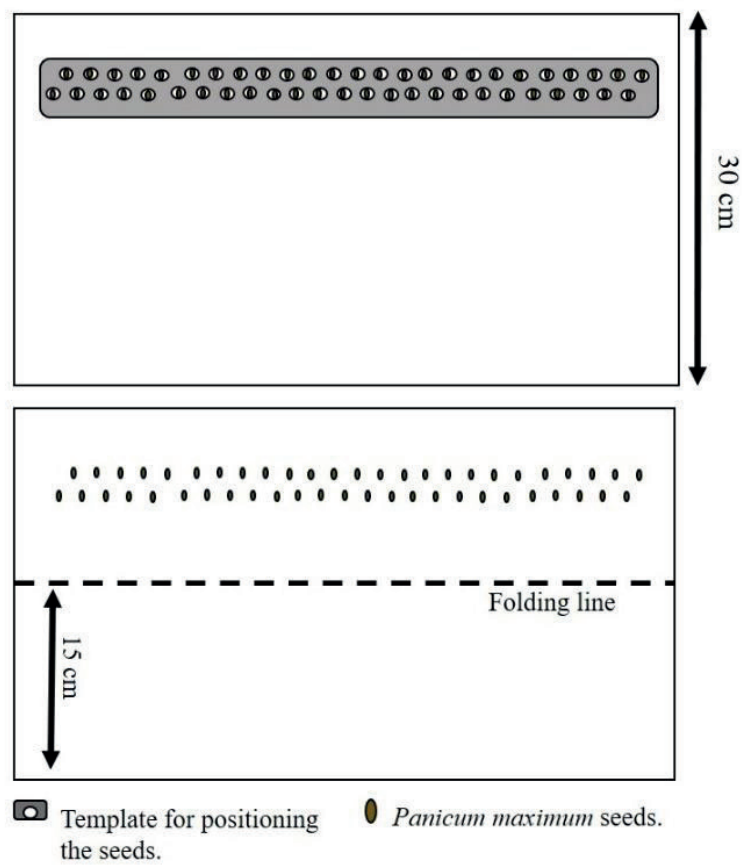

Germination and first count test: The germination test was conducted in a germination chamber at $20-30{ }^{\circ} \mathrm{C}$, with an eight-hour photoperiod for both methods. The first germination count was evaluated on the $10^{\text {th }}$ day after sowing, through the percentage of normal seedlings. The final germination count (normal seedlings) was performed on the $28^{\text {th }}$ day after sowing, and the data were expressed as percentages (MAPA, 2009).

The experiment was conducted with an entirely randomized design. The data were analyzed in a $2 \times 8$ factor scheme (sowing methods $x$ lots), with four repetitions. The data were checked for normality and homogeneity of variance, using the Shapiro-Wilk test, after which they were subjected to analysis of variance using the $\mathrm{F}$ test; when significant, the treatment means were compared using the Scott-Knott test at $5 \%$ probability.

B
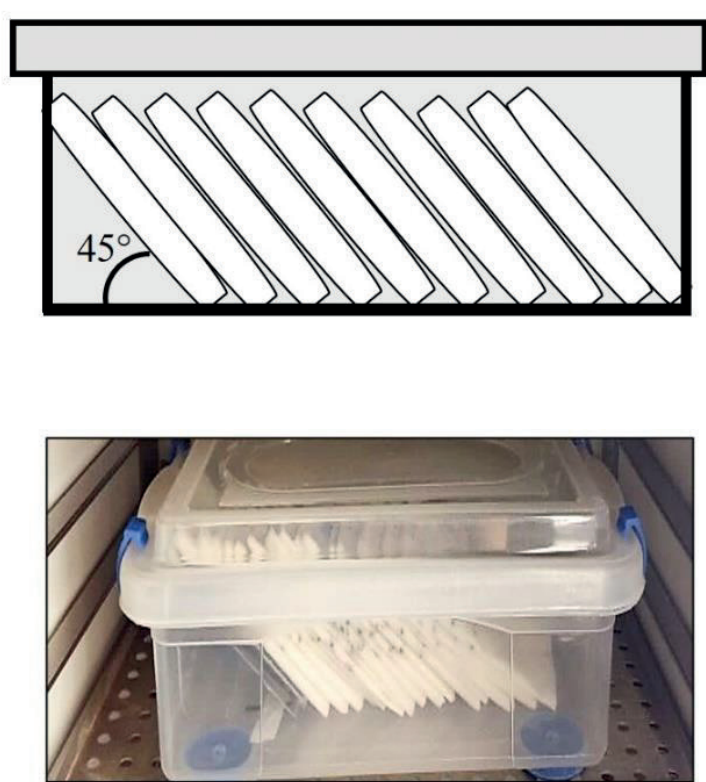

Figure 1. Image of the seeds being positioned on the germitest leaf with the template and marking of the leaf fold (A). Envelopes accommodated in a plastic box forming a $45^{\circ}$ slope to the base of the box, and allocation of the boxes inside the chamber during the germination test (B). 
The initial water content of the seeds was similar for the nine lots evaluated, ranging from 9.0 to $10.0 \%$. Therefore, seed germination differences could be attributed to the physiological quality of seeds (G. Z. da Silva et al., 2017; Melo et al., 2018; Pereira et al., 2020). There was a significant correlation between the sowing methods and the lots for all parameters evaluated (Table 1).

Both the germination percentage and the germination speed, evaluated by the first count test, showed that in $100 \%$ of the lots, the envelope method was equivalent or superior to the traditional sowing on paper method. The germination of the eight lots used in this study was above $40 \%$ when the test was conducted using the envelope method. Therefore, the seeds could be sold, since they meet the official P. maximum (MAPA, 2008) seed standards.

The results of the envelope method for the germination and first count tests showed that lots $5,6,7$, and 8 had medium to low vigor seeds, with less than $59 \%$ germination, while the other lots had high vigor seeds, according to Pereira et al. (2020). The comparison between lots showed that the envelope method allowed a superior, more uniform germination performance of the seeds than the traditional paper method. Half of the lots showed no difference between the sowing methods.

Similarly, a study by R. C. da, Grzybowski and Panobianco (2016) with maize seeds reported that, depending on the substrate, higher and lower vigor lots could show similar performances, proving that the substrate has a greater effect on the results than the physiological quality of the seeds in germination and seedling vigor tests. However, there have also been reports that high vigor fodder pea and safflower lots were less demanding on substrate conditions than low vigor lots (Gama et al., 2019; Machado, Martins, Silva Cruz, Assis, 2019b).

Therefore, each species has different germination responses due to ecological adaptation to the places of origin, so, a large number of lots should be used to assure the results of studies on the evaluation of germination methods (G. Z. da Silva et al., 2017, 2019; Pereira et al., 2020). 
Table 1

Analysis of variance and mean germination, first count, and abnormal seedlings values for nine lots of Mombasa grass seeds according to the sowing method, envelope or paper

\begin{tabular}{|c|c|c|c|c|c|c|}
\hline \multirow{3}{*}{ Lots } & \multicolumn{2}{|c|}{ Germination } & \multicolumn{2}{|c|}{ First count } & \multicolumn{2}{|c|}{ Abnormal seedlings } \\
\hline & \multicolumn{6}{|c|}{-----------------------------------------\%0------------------------------------------ } \\
\hline & Envelope & Paper & Envelope & Paper & Envelope & Paper \\
\hline L1 & $82 \mathrm{Aa}$ & $50 \mathrm{Bb}$ & $82 \mathrm{Aa}$ & $50 \mathrm{Bb}$ & $2 \mathrm{Aa}$ & $23 \mathrm{Bb}$ \\
\hline L2 & $81 \mathrm{Aa}$ & $67 \mathrm{Ba}$ & $81 \mathrm{Aa}$ & $67 \mathrm{Ba}$ & $2 \mathrm{Aa}$ & $11 \mathrm{Ba}$ \\
\hline L3 & $78 \mathrm{Aa}$ & $57 \mathrm{Ba}$ & $78 \mathrm{Aa}$ & $57 \mathrm{Ba}$ & $4 \mathrm{Aa}$ & $22 \mathrm{Bb}$ \\
\hline L4 & $62 \mathrm{Ab}$ & $34 \mathrm{Bc}$ & $62 \mathrm{Ab}$ & $34 \mathrm{Bc}$ & $8 \mathrm{Aa}$ & $27 \mathrm{Bb}$ \\
\hline L5 & $57 \mathrm{Ab}$ & $48 \mathrm{Ab}$ & $57 \mathrm{Ab}$ & $48 \mathrm{Ab}$ & $2 \mathrm{Aa}$ & $10 \mathrm{Aa}$ \\
\hline L6 & $57 \mathrm{Ab}$ & $61 \mathrm{Aa}$ & $57 \mathrm{Ab}$ & $61 \mathrm{Aa}$ & $4 \mathrm{Aa}$ & $11 \mathrm{Aa}$ \\
\hline L7 & $53 \mathrm{Ab}$ & $46 \mathrm{Ab}$ & $53 \mathrm{Ab}$ & $45 \mathrm{Ab}$ & $4 \mathrm{Aa}$ & $20 \mathrm{Bb}$ \\
\hline L8 & $41 \mathrm{Ac}$ & $39 \mathrm{Ac}$ & $41 \mathrm{Ac}$ & $39 A b$ & $17 \mathrm{Ab}$ & $20 \mathrm{Ab}$ \\
\hline Method (M) & \multicolumn{2}{|c|}{$2.787,55^{\star \star}$} & \multicolumn{2}{|c|}{$2.812,50^{* *}$} & \multicolumn{2}{|c|}{$2.380,50^{* *}$} \\
\hline Lots (L) & \multicolumn{2}{|c|}{$2.799,80^{* *}$} & \multicolumn{2}{|c|}{$2.813,84^{* *}$} & \multicolumn{2}{|c|}{$217,18^{* *}$} \\
\hline$M \times L$ & \multicolumn{2}{|c|}{$306,30 * *$} & \multicolumn{2}{|c|}{$300,65^{* *}$} & \multicolumn{2}{|c|}{$104,12^{* *}$} \\
\hline CV (\%) & \multicolumn{2}{|c|}{15,99} & \multicolumn{2}{|c|}{16,02} & \multicolumn{2}{|c|}{49,25} \\
\hline
\end{tabular}

** = significant at $1 \%$ probability and not significant according to the F test. Means followed by the same lower-case letter in the column and upper-case letter in the row within each variable do not differ by the Scott-Knott test at $5 \%$ probability.

Lots 1, 2, 3 and 4 had higher mean germination and first count by the envelope method than by the traditional method, with an addition of up to 32 percentage points. These results validated the utility of the envelope method for the germination test of Mombasa grass seeds, as reported for onion seeds by Jeromini et al. (2019).

The percentage of abnormal seedlings corroborated with those obtained at germination and first count, as it also showed that the envelope method was better or equal to the traditional method. Seeds from lower vigor lots, such as 8 , resulted in a higher percentage of abnormal seedlings $(17 \%)$ by the envelope method, while the others were between 2 and $8 \%$.
In general, the lower percentage of abnormal seedlings in the envelope test may be attributed to higher substrate aeration, which favors better seedling development. When positioned at $45^{\circ}$ inside the plastic boxes, the envelope method allowed gravity drainage of the excess water from the substrate, increasing aeration and seedling formation (Figure 1B). These phenomena explain the lower percentage of abnormal seedlings and the higher germination speed and percentage of Mombasa grass seeds.

Lack of $\mathrm{O}_{2}$ during the germination process caused by excess water in the substrate impairs respiration, slowing down or stopping the development of the embryonic axis, and may thus increase the occurrence 
of abnormal seedlings (Carvalho \& Nakagawa, 2012). The promising results obtained in this study and the one conducted by Jeromini et al. (2019) with onion seeds show that the envelope method should be evaluated with other species whose seeds are small in size and whose germination test is usually conducted using the traditional paper method in transparent plastic boxes.

The RAS (MAPA, 2009) norms and procedures are periodically reviewed by a committee comprising researchers and professionals in the field. However, changes can only be made based on research results (MAPA, 2009; Tomaz et al., 2016).

Additionally, the envelope method is faster and more practical than the use of conventional transparent plastic boxes, as it excludes the requirement for cleaning of a large number of small plastic boxes before and after the test, and its installation is facilitated by the use of the template ruler, which allows time and labor savings in the seed analysis laboratory (Jeromini et al., 2019). Better use of space in germination chambers was also observed. Each germination chamber could hold five plastic boxes with 40 envelopes each totaling 200 subsamples, while the traditional method would allow the allocation of only 60 subsamples, that is, 60 boxes.

The envelope method is efficient for the germination test of Mombasa grass seeds and can be easily used in seed analysis laboratories, with results equal or superior to those obtained with the traditional paper method, while occupying only $2 / 5$ of the germination chamber space used in the conventional method.

\section{Acknowledgments}

The authors thank Marangatú Seeds for supplying the seeds.

\section{Conflict of interest}

The authors declare no conflict of interest related to the research, authorship, or publication of this article.

\section{References}

Associação Brasileira de Sementes e Mudas (2016). Anuário 2016. Recuperado de http://www.abrasem.com.br/wpContent/uploads/2013/09/Anuario_ ABRASEM_2016_SITE.pdf

Carvalho, N. M., \& Nakagawa, J. (2012). Sementes: ciência, tecnologia e produção (5a ed.). Jaboticabal: FUNEP.

Gama, G. F., Machado, C. G., Silva, G. Z. da, Moraes, A. L. C., Silva, A. A. S., \& Lima e Silva, I. M. H. de. (2019). Substrates and duration for conducting the safflower seed germination test. Científica, 47(4), 426433. doi: 10.15361/1984-5529.2019v47n 4p426-433

Gaspar-Oliveira, C. M., Martins, C. C., Nakagawa, J., \& Tomaz, C. de A. (2007) Maintenance of substrate moisture during Brachiaria brizantha germination test. Revista Brasileira de Sementes, 29(3), 52-60. doi: 10.1590/S0101-31222007000300007

Jeromini, T. S., Muniz, R. A., Silva, G. Z. D., \& Martins, C. C. (2019). The envelope method and substrate wetting in the germination test of onion seeds. Revista Ciência Agronômica, 50(1), 169-176. doi: 10.59 35/1806-6690.20190020 
Machado, C. G, Cruz, S. C. S., Silva, G. Z. da, Carneiro, L. C., \& Silva, I. M. de L. (2019a). Harvesting methods on physical and physiological quality of Panicum maximum seeds. Revista Brasileira de Engenharia Agrícola e Ambiental, 23(4), 309-313. doi: 10.1590/1807-1929/agriambi.v23n4p309 $-313$

Machado, C. G., Martins, C. C., Silva, G. Z., Cruz, S. C. S., \& Assis, R. M. (2019b). Adequacy of methodology for conducting germination test in forage pea seeds. Bioscience Journal, 35(2), 367-376. doi: 10.14393/ BJ-v35n2a20198-41747

Melo, L. F. de, Martins, C. C., Silva, G. Z., Pereira, F. E. C. B., \& Jeromini, T. S. (2018). Effects of processing phases on the quality of massai grass seeds. Revista Ciência Agronômica, 49(2), 259-266. doi: 10.5935/1806-6690.20180029

Mendonça, V. Z., Mello, L. M., Pereira, F. C., Silva, J. O. D. R., \& Yano, É. H. (2014). Corn production for silage intercropped with forage in the farming-cattle breeding integration. Revista Engenharia Agrícola, 34(4), 738-745. doi: 10.1590/S0100-6916 2014000400013

Ministério da Agricultura, Pecuária e Abastecimento (2008). Instrução Normativa $n^{\circ} 30$, de 21 de maio de 2008. Dispõe das normas e padrões para produção e comercialização de sementes de espécies forrageiras de clima tropical. Diário Oficial da República Federativa do Brasil, Ministério da Agricultura, Pecuária e Abastecimento, Brasília, 2008.
Ministério da Agricultura, Pecuária e Abastecimento (2009). Regras para análise de sementes. Secretaria de Defesa Agropecuária. Brasília: MAPA/ACS.

Pereira, F. E. C. B., Martins, C. C., Jeromini, T. S., Gomes, F. G., Jr., \& Torres, S. B. (2020). Tests to evaluate the physiological potential of Mombasa grass seeds. Revista Ciência Agronômica, 51(1), e20186359. doi: 10.59 35/1806-6690.20200009

Silva, G. Z. da, Martins, C. C., Bruno, R. de L. A., Pereira, F. E. C. B., \& Jeromini, T. S. (2019). Multivariate analysis and vigor tests to determine the quality of Brachiaria decumbens seeds. Revista Ciência Agronômica, 50(2), 291-299. doi: 10.5935/1806-6690.20190034

Silva, G. Z. da, Martins, C. C., Cruz, J. de O., Jeromini, T. S., \& Bruno, R. de L. A. (2017). Evaluation the physiological quality of Brachiaria brizantha cv. BRS Piatã seeds. Bioscience Journal, 33(3), 572-580, doi: 10.14393/BJ-v33n3-36519

Silva, R. C. da, Grzybowski, C. R. de S., \& Panobianco, M. (2016). Vigor de sementes de milho: influência no desenvolvimento de plântulas em condições de estresse salino. Revista Ciência Agronômica, 47(3), 491-499. doi: 10.5935/1806-6690. 20160059

Tomaz, C. A., Martins, C. C., Silva, G. Z., \& Vieira, R. D. (2016). Period of time taken by Brachiaria humidicola (Rendle) Schweick seed to complete germination. Semina: Ciências Agrárias, 37(2), 693-700. doi: 10. 5433/1679-0359.2016v37n2p693 